\title{
Investigation of the magnetic properties of soils in the Cisna-Wetlina Landscape Park
}

\author{
Tomasz Gonet ${ }^{1}$, Anna Wojas ${ }^{2}$ \\ ${ }^{1}$ University of Warsaw, Faculty of Geology; ul. Żwirki i Wigury 93, 02-089 Warsaw, Poland; e-mail: tgonet@igf.edu.pl \\ ${ }^{2}$ AGH University of Science and Technology, Faculty of Geology, Geophysics and Environmental \\ Protection; al. A. Mickiewicza 30,31-871 Krakow, Poland; e-mail: awojas@agh.edu.pl
}

\begin{abstract}
(C) 2016 Authors. This is an open access publication, which can be used, distributed and reproduced in any medium according
\end{abstract} to the Creative Commons CC-BY 4.0 License requiring that the original work has been properly cited.

Received: 17 October 2015; accepted: 8 March 2016

\begin{abstract}
A magnetic study of 16 samples of topsoil and 2 soil profiles (11 samples) in the area of Cisna-Wetlina Landscape Park was carried out. The whole collection of the samples represents typical Carpathian soils - brown and sour. Magnetic susceptibility, frequency, dependence of magnetic susceptibility, temperature dependence of magnetic susceptibility, thermal decay of saturation, isothermal remanent magnetization, parameters of hysteresis loop and anhysteretic remanent magnetization of the samples were measured in a laboratory. Mass magnetic susceptibility of topsoil specimens is below $40 \cdot 10^{-8} \mathrm{~m}^{3} \cdot \mathrm{kg}^{-1}$, which indicates that the investigated area is probably not polluted currently. The study of the samples from two soil profiles reveals a slight enhancement of magnetic susceptibility in the upper horizons, presumably related to natural processes. The temperature dependence of magnetic susceptibility and saturation isothermal remanence of four soil samples show that the presence of iron sulphide minerals (pyrrhotite) and maghemite is associated with hematite. The occurrence of other iron sulphide minerals in the soil is also possible. The saturation isothermal remanence curves do not confirm the presence of magnetite. Studies of the hysteresis loop reveal a significant role of paramagnetics among magnetic minerals occurring in the samples. Hysteresis parameters (coercive force, coercivity of remanence, saturation magnetization, isothermal remanent magnetization) and anhysteretic remanent susceptibility allowed the authors to evaluate the grain size distribution and reveal the presence of pseudo-single domain (PSD) grains.
\end{abstract}

Keywords: environmental magnetism, magnetic properties, soils, pollution, Bieszczady Mountains

\section{INTRODUCTION}

The paper concerns the reconnaissance magnetic investigations of soils in the Cisna-Wetlina Landscape Park.

Magnetic susceptibility is a basic magnetic parameter, widely used in environmental studies. It is defined as the ability of matter to magnetize under the influence of an external magnetic field (Grabowska 2013). This parameter is utilized to assess the state of environmental pollution and characterize occurring magnetic particles. Investigations of magnetic susceptibility of various natural materials have been conducted, for instance: soil (Magiera et al. 2008, Wojas 2009, Magiera et al. 2011b), peat (Strzyszcz \& Magiera 2001), ochre deposit (Wojas et al. 2010), loess (Heller \& Evans 1995), bottom sediments of lakes (Magiera et al. 2002b, Magiera 2004, Kusza 2013), airborne particulate matter (Sagnotti et al. 2009, Magiera et al. 2011a), indoor dust (Jordanova et al. 2012, Górka-Kostrubiec et al. 2014), tree leaves (Szönyi et al. 2007, Rodríguez-Germade et al. 2014), fruits of the forest and mushrooms (Strzyszcz \& Rachwał 2010).

Most of the attention has been focused on the investigation of soil, which is one of the most 
important components of the environment. In this respect, the subject of interest can be topsoil (usually to the depth of $10 \mathrm{~cm}$ ) and soil profiles.

In the case of topsoil studies, magnetic susceptibility is closely related to the content of iron oxide particles, which are almost always accompanied by heavy metals and polycyclic aromatic hydrocarbons (Strzyszcz \& Rachwał 2010). Numerous studies of topsoil proved that investigations of magnetic susceptibility can be simple tools used in the analysis of soil pollution.

The results of topsoil magnetic susceptibility investigations are often presented as maps. In a polluted area, an anomaly of magnetic susceptibility of soil can be noted. Its intensity is indirectly related to the content of heavy metals, such as $\mathrm{Pb}$, $\mathrm{Zn}, \mathrm{Cd}, \mathrm{Cu}, \mathrm{Ni}, \mathrm{Co}, \mathrm{V}$ and Cr (Magiera 2004).

In the other case, magnetic studies of the soil environment can be concentrated on soil pits. Here, the origin of magnetic minerals can be described by the shape of the curves of magnetic susceptibility vs. depth. Such presentation of investigation results yields information about the content of magnetic minerals and the transformations of the state of minerals, caused by changes of physico-chemical conditions in the soil profile.

Additionally, studies of different magnetic parameters (magnetic susceptibility, frequency dependence of magnetic susceptibility, anhysteretic remanent susceptibility, coercive force, coercivity of remanence, saturation magnetization, isothermal remanent magnetization), their interrelationships and changes in temperatures (magnetic susceptibility, saturation isothermal remanent magnetization) allow one to identify the magnetic minerals and determine the granulation and content of those minerals in soil (Peters \& Dekkers 2003).

\section{THE INVESTIGATED AREA}

The Cisna-Wetlina Landscape Park is located in south-eastern Poland, within two tectonic units of the Eastern Flysch Carpathians: the Silesian Unit and the Dukla Unit (Fig. 1). The area of interest belongs to the Dukla Unit (Gucik et al. 1973) in the south-western part of the Cisna-Wetlina Landscape Park.

The Dukla Unit is characterized by typical flysch sediments - mainly the Upper Cretaceous, Palaeocene and Eocene formations of alternate layers of sandstones and shales. In the investigated area, this unit is represented by among others Krosno beds (grey, micaceous sandstones interbedded by shales), hieroglyphic beds (greyish green, clay shales and fine grained sandstones) and globigerina marls (yellowish green marls with numerous globigerina). The parent material of soils, which has been formed from those rocks, is not magnetic.

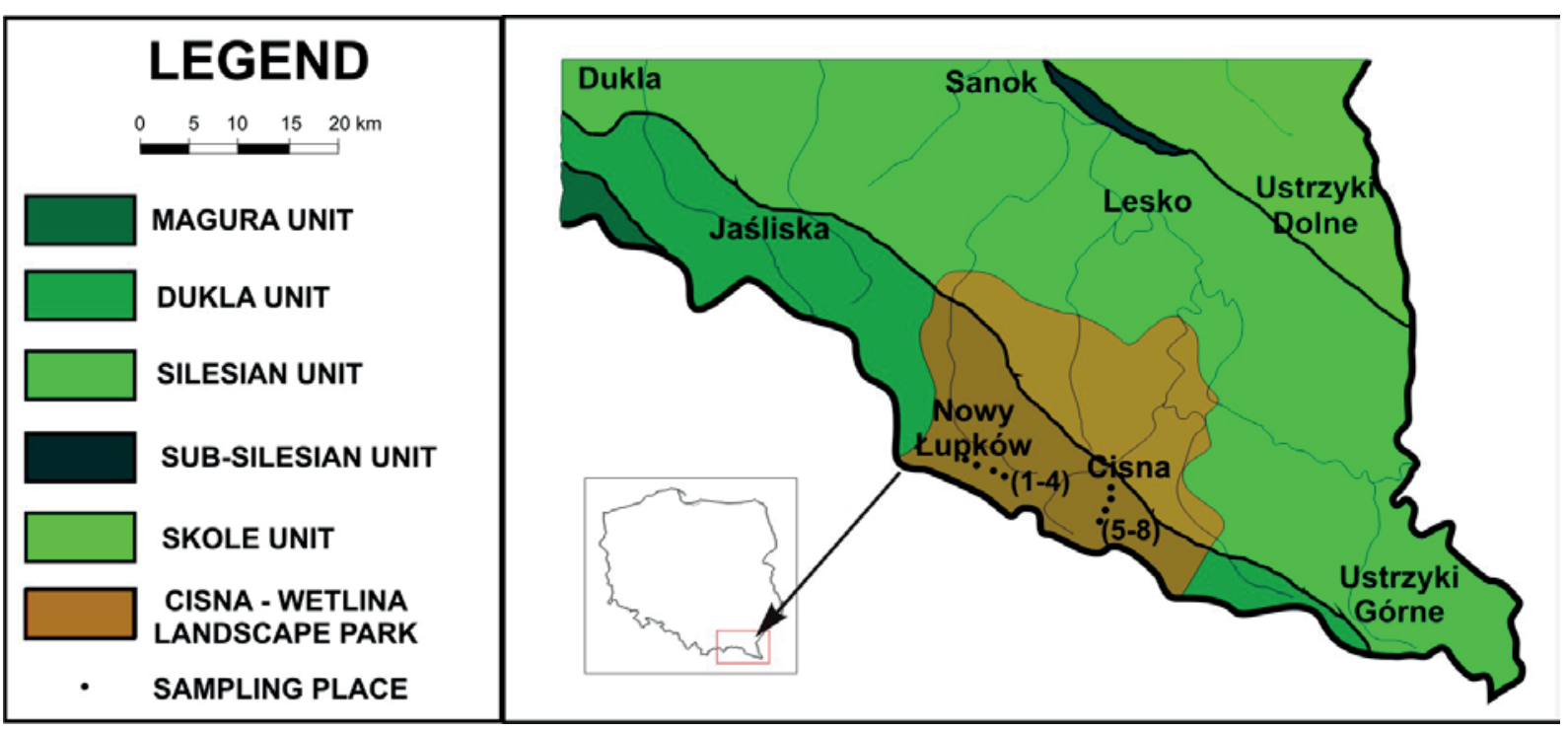

Fig. 1. Schematic map of tectonic units in south-eastern Poland, with locations of sampling places (Gucik et al. 1973 - modified) 
The hypergenesis phenomena existing in the Carpathian Flysch in the Tertiary (Królikowski et al. 1986) made the formation of horizons possible, consisting mainly of brown and sour soils.

\section{PREVIOUS STUDIES}

In the studied area the first magnetic research was carried out in 2002. It concerned the magnetic susceptibility of soils and was carried out on samples collected in 1991-1992. The results of this study were described in the Magnetic Susceptibility of Soils in Poland (Magiera et al. 2002a). Very high values (above $200 \cdot 10^{-8} \mathrm{~m}^{3} \cdot \mathrm{kg}^{-1}$ ) of magnetic susceptibility were noted in the western part of the Cisna-Wetlina Landscape Park (Fig. 2). Magiera (2004) has formulated a hypothesis, that the industrial complex in Košice was the main cause of this anomaly, and pollution from Slovakia was blown on the Polish territory in numerous passes, most of all through the Łupków Pass.
Nevertheless, geochemical studies of the same samples (Lis \& Pasieczna 1995) have shown that the limit values (Rozporzadzenie Ministra Środowiska... 2002) of the investigated elements are not exceeded. The content of heavy metals in soils is: $20-40 \mathrm{ppm}$ for nickel (the limit value is $100 \mathrm{ppm}$ ), $10-20 \mathrm{ppm}$ for chrome (the limit value is $150 \mathrm{ppm}$ ), $40-80 \mathrm{ppm}$ for copper (the limit value is $150 \mathrm{ppm}$ ) and in the case of iron: $2-4 \%$.

\section{METHODS}

The magnetic studies have been conducted on 27 soil samples from the Cisna-Wetlina Landscape Park. The 16 topsoil samples were collected with a soil probe at eight sites (Fig. 1). At each site, the investigated material was collected in two sampling places located a few meters from each other (samples I and II), according to the adopted methodology, namely after removing the uppermost part of the organic horizon (i.e. litter layer)

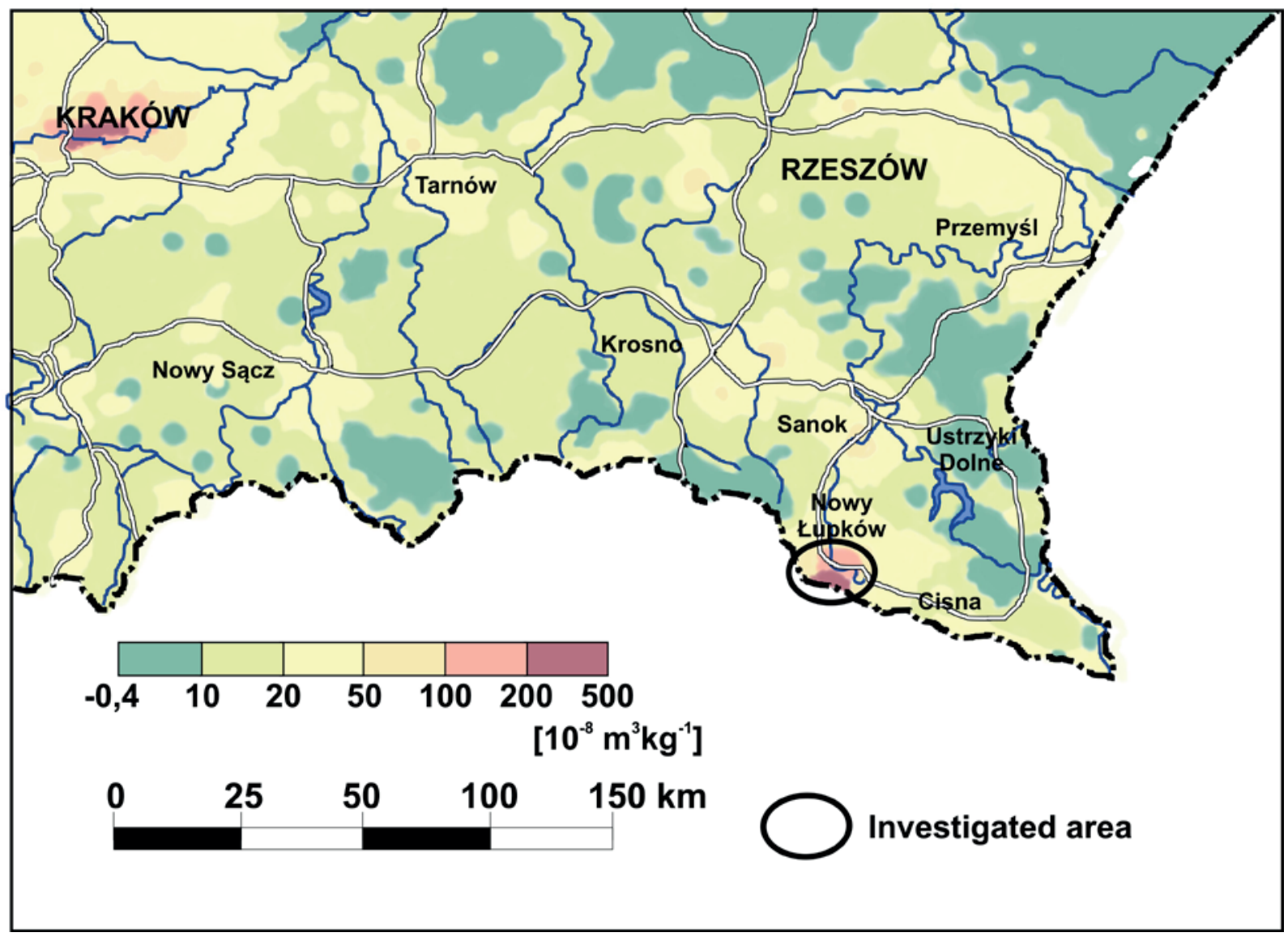

Fig. 2. Fragment of the map of mass susceptibility of topsoil in south-eastern Poland (Magiera et al. 2002a-modified) 
(Strzyszcz \& Rachwał 2010). The samples mainly come from the depth range of $0-4 \mathrm{~cm}$. Additionally, in two previously designated sites, 11 samples (in total) were collected from the soil pits to the depth of $35 \mathrm{~cm}$. The entire material was dried and crumbled before the measurements.

Laboratory magnetic studies were carried out in the Laboratory of Petrophysics, Department of Geophysics (Faculty of Geology, Geophysics and Environmental Protection, AGH University of Science and Technology in Cracow) and in the Paleomagnetic Laboratory of the Institute of Geophysics, Polish Academy of Sciences in Warsaw. The investigations included: volume and mass magnetic susceptibility (Bartington MS2), frequency dependence of magnetic susceptibility (Bartington MS2), temperature dependence of magnetic susceptibility (AGICO KLY 3S), temperature dependence of saturation isothermal remanent magnetization (Magnetic Measurements MMPM10, TUS), hysteresis loop with saturation magnetization, isothermal remanent magnetization, coercive force and coercivity of remanence (Molspin VSM) and anhysteretic remanent susceptibility (AGICO LDA-3, 2G Enterprises SQUID DC).

Magnetic susceptibility is one of the most basic magnetic parameters. In the case of volume magnetic susceptibility $(\kappa)$, it is defined as a ratio of induced magnetization $\left(M_{i}\right)$ and intensity of the magnetic field $(H)$ :

$$
\text { }=\frac{M_{i}}{H}[-]
$$

In the soil studies, mass magnetic susceptibility $(\chi)$ concerning the volume density $(\rho)$ of the sample is more commonly used:

$$
\chi=\frac{\kappa}{\rho}\left[\mathrm{m}^{3} \cdot \mathrm{kg}^{-1}\right]
$$

Magnetic susceptibility values above $100 \cdot 10^{-8}$ $\mathrm{m}^{3} \cdot \mathrm{kg}^{-1}$ characterize polluted soils in the forest areas, in which the concentration of at least one heavy metal exceeds the limit value (Magiera 2004).

Frequency dependence of magnetic susceptibility $\left(\kappa_{f d}\right)$ corresponds to the sensitivity of the magnetic grains due to the changes in intensity of the magnetic field. This parameter describes the percentage decrease of susceptibility during the increase of the frequency of the magnetic field:

$$
\kappa_{f d}=\frac{\kappa_{l f}-\kappa_{h f}}{\kappa_{l f}} \cdot 100[\%]
$$

where:

$\kappa_{l f}$ - magnetic susceptibility in low frequency of the magnetic field $(465 \mathrm{~Hz})$,

$\kappa_{h f}-$ magnetic susceptibility in high frequency of the magnetic field $(4650 \mathrm{~Hz})$.

Superparamagnetic (SP) and stable single-domain (SSD) particles are characterized by $\kappa_{f d}$ higher than 5-6\%, whereas for multi-domain (MD) grains, lower values of $\kappa_{f d}$ are expected (van Oorschot 2001).

Studies of temperature dependence of the soil magnetic susceptibility were carried out during heating (from room temperature to $700^{\circ} \mathrm{C}$ ) and cooling processes. The analysis of the susceptibility changes with temperature is quite complicated due to phase alterations occurring in the samples during measurements. Therefore, sometimes it is not possible to determine the critical (Curie or Néel) temperature of the initially existing magnetic minerals in soil samples (Jeleńska et al. 2008).

The investigations of thermal demagnetization of saturation isothermal remanence (SIRM) are a better proxy for evaluating magnetic minerals because SIRM(T) curves are not distorted by mineralogical transformations during heating (Jeleńs$\mathrm{ka}$ et al. 2010). As a result, it is possible to determine the critical temperatures of the originally occurring magnetic minerals. The remanence was imparted on samples in the field of 9T and measured from the room temperature up to $700^{\circ} \mathrm{C}$.

In order to evaluate magnetic grain size the measurements of saturation magnetization $\left(M_{s}\right)$, saturation isothermal remanent magnetization $\left(M_{r s}\right)$, coercive force $(B)$ and coercivity of remanence $\left(B_{c r}\right)$ were taken. These parameters characterize the shape of the hysteresis loop, which is the magnetization dependence of the magnetic field intensity.

The measurements of hysteresis loop parameters have been supported by studies of the anhysteretic remanent susceptibility $\left(\chi_{\text {ARM }}\right)$, which is a parameter concerning the mass-normalized anhysteretic remanent magnetization (expressed in $\left.\mathrm{A} \cdot \mathrm{m}^{2} \cdot \mathrm{kg}^{-1}\right)$ bias the intensity of the magnetic field $\left(A \cdot \mathrm{m}^{-1}\right)$. The parameter is sensitive to the presence 
of ferromagnetic single-domain particles and increases with the growth of the SD grains content in a sample (Evans \& Heller 2003). $\chi_{\text {ARM }}$ was measured for four specimens at random.

\section{RESULTS}

Table 1 shows the magnetic susceptibility of topsoil samples collected in the Cisna-Wetlina Landscape Park. Relatively low values have been noted. Low-frequency mass susceptibility ranges between (10.3-38.2) $10^{-8} \mathrm{~m}^{3} \cdot \mathrm{kg}^{-1}$ and high-frequency susceptibility, between $(9.9-36.8) \cdot 10^{-8} \mathrm{~m}^{3} \cdot \mathrm{kg}^{-1}$. Magnetic susceptibility of only one sample, collected near Cisna (7.I sampling site), stands out among others reaching $38.2 \cdot 10^{-8} \mathrm{~m}^{3} \cdot \mathrm{kg}^{-1}$.

Susceptibility of polluted soils usually exceeds $50 \cdot 10^{-8} \mathrm{~m}^{3} \cdot \mathrm{kg}^{-1}$ (Magiera \& Strzyszcz 2003), and therefore we suggest that soils in the Cisna-Wetlina Landscape Park are probably not polluted currently.

It is worth emphasizing that the received susceptibilities generally fall into the range of typical values for non-polluted Carpathian soils (brown, sour). They normally do not exceed $20 \cdot 10^{-8} \mathrm{~m}^{3} \cdot \mathrm{kg}^{-1}$ (Magiera et al. 2002a).
The frequency dependence of magnetic susceptibility varies in a wide range - from $2.7 \%$ to $9.1 \%$ (Tab. 1). Sample 6.II, located near Cisna, exhibits a very high $\kappa_{f d}(9.1 \%)$, which may indicate the presence of SP/SSD particles (van Oorschot 2001). Nevertheless, the value for the second sample from that same place (6.I) is lower than $5 \%$. Values of frequency-dependent susceptibility for other samples do not exceed $7.1 \%$. It is very difficult to draw an accurate conclusion, and therefore we deemed this parameter inconclusive and excluded it from further consideration.

The distribution of magnetic susceptibility in the two soil profiles is shown in Figure 3. The behaviour of $\chi$ along the profiles is similar i.e. very low values at the bottom part (around $5 \cdot 10^{-8} \mathrm{~m}^{3} \cdot \mathrm{kg}^{-1}$ ) increasing towards the top. The soil profile from the outside of the anomaly area has higher values of topsoil susceptibility, reaching nearly $19 \cdot 10^{-8} \mathrm{~m}^{3} \cdot \mathrm{kg}^{-1}$, while $\chi$ for the topsoil in the anomaly area does not exceed $12 \cdot 10^{-8} \mathrm{~m}^{3} \cdot \mathrm{kg}^{-1}$. In the anomaly area, magnetic susceptibility of the soil is stabilizing at the depth of $20-35 \mathrm{~cm}$, reaching ca. $6 \cdot 10^{-8} \mathrm{~m}^{3} \cdot \mathrm{kg}^{-1}$.

Table 1

Volume magnetic susceptibility $(\kappa)$, mass magnetic susceptibility $(\chi)$ measured in low $\left(\kappa_{l f}, \chi_{l f}\right)$ and high $\left(\kappa_{h f}, \chi_{h f}\right)$ frequency of the magnetic field and frequency-dependent susceptibility $\left(\kappa_{f d}\right)$ of samples from the depth range of $0-4 \mathrm{~cm}$

\begin{tabular}{|c|c|c|c|c|c|c|c|}
\hline & $\begin{array}{l}\text { Sampling } \\
\text { place }\end{array}$ & $\begin{array}{l}\text { Number } \\
\text { of sample }\end{array}$ & $\kappa_{1 f^{10}} 10^{-5}[-]$ & $\kappa_{\mathrm{hf}} \cdot 10^{-5}[-]$ & $\kappa_{\mathrm{fd}}[\%]$ & $\begin{array}{l}\chi_{\mathrm{lf}} \cdot 10^{-8} \\
{\left[\mathrm{~m}^{3} / \mathrm{kg}\right]}\end{array}$ & $\chi_{\mathrm{hf}} \cdot 10^{-8}\left[\mathrm{~m}^{3} / \mathrm{kg}\right]$ \\
\hline \multirow{8}{*}{$\begin{array}{l}\text { The anomaly } \\
\text { area } \\
\text { (near Nowy } \\
\text { Eupków) }\end{array}$} & \multirow{2}{*}{1} & I & 12.2 & 11.6 & 5.2 & 17.5 & 16.6 \\
\hline & & II & 10.6 & 9.8 & 7.1 & 21.1 & 19.6 \\
\hline & \multirow{2}{*}{2} & I & 10.7 & 10.1 & 5.9 & 19.6 & 18.4 \\
\hline & & II & 22.2 & 21.0 & 5.6 & 27.8 & 26.3 \\
\hline & \multirow{2}{*}{3} & I & 8.4 & 8.0 & 4.5 & 10.3 & 9.9 \\
\hline & & II & 9.2 & 8.9 & 2.7 & 13.8 & 13.4 \\
\hline & \multirow{2}{*}{4} & I & 7.5 & 7.3 & 3.3 & 11.4 & 11.0 \\
\hline & & II & 7.2 & 6.9 & 3.5 & 10.4 & 10.1 \\
\hline \multirow{8}{*}{$\begin{array}{l}\text { The area } \\
\text { outside the } \\
\text { anomaly } \\
\text { (near Cisna) }\end{array}$} & \multirow{2}{*}{5} & I & 19.2 & 18.1 & 5.9 & 29.2 & 27.5 \\
\hline & & II & 13.6 & 12.8 & 5.6 & 18.4 & 17.4 \\
\hline & \multirow{2}{*}{6} & I & 13.6 & 12.9 & 4.6 & 19.8 & 18.9 \\
\hline & & II & 12.4 & 11.3 & 9.1 & 16.4 & 14.9 \\
\hline & \multirow{2}{*}{7} & $\mathrm{I}$ & 10.1 & 9.7 & 3.8 & 38.2 & 36.8 \\
\hline & & II & 9.6 & 9.0 & 5.3 & 20.2 & 19.1 \\
\hline & \multirow{2}{*}{8} & I & 17.8 & 17.0 & 4.9 & 22.5 & 21.4 \\
\hline & & II & 15.3 & 14.3 & 6.6 & 20.0 & 18.7 \\
\hline
\end{tabular}




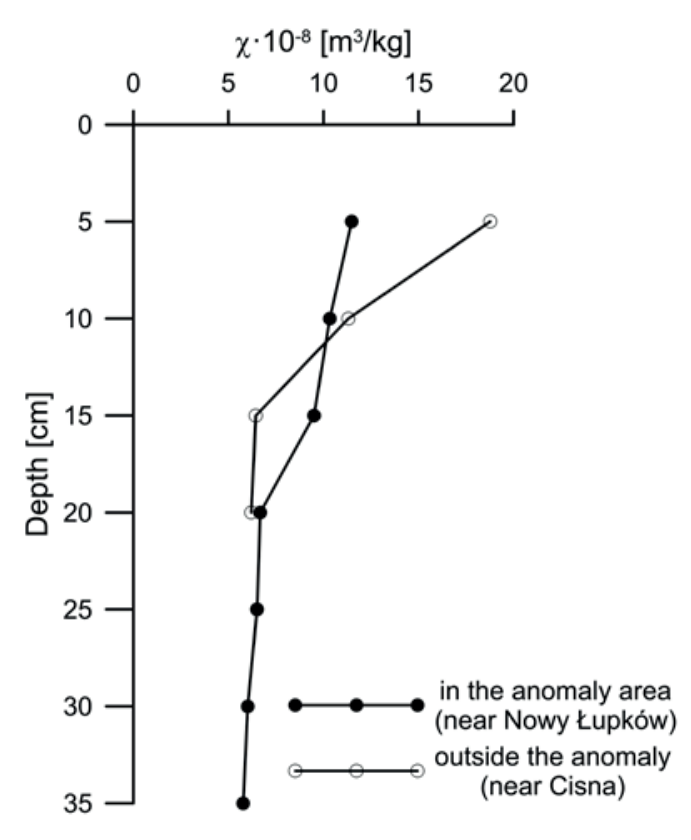

Fig. 3. Distribution of mass magnetic susceptibility $(\chi)$ in the soil profiles

Figure 4 presents the curves of susceptibility changes during continuous heating and cooling for two samples: the first one, from the area of the anomaly near Nowy Łupków (2.II) and the second one, from outside the anomaly near Cisna (8.I). They exhibit almost the same behaviour. The curves show a Curie temperature near $580^{\circ} \mathrm{C}$, which is characteristic for magnetite. We consider the enhancement of $\kappa$ around $250-280^{\circ} \mathrm{C}$ to be related to the oxidation of pyrrhotite into magnetite (Kądziałko-Hofmokl 2002). The transformation of the antiferromagnetic phase represented by hexagonal pyrrhotite into its ferrimagnetic form is also possible. In this case, above the temperature of $200^{\circ} \mathrm{C}$, a monoclinic pyrrhotite is formed (Dunlop \& Özdemir 2007). The decrease observed in the range $280-400^{\circ} \mathrm{C}$ points to the alteration of some grains of maghemite into hematite (Jeleńska et al. 2004). The partial alteration of maghemite depends on its size, because only finegrained maghemite can be completely converted to hematite in the temperature range ca. 300$400^{\circ} \mathrm{C}$ (de Boer \& Dekkers 1996). Additionally, for all samples, the increase of $\kappa$ around $450-500^{\circ} \mathrm{C}$ can be observed. We tentatively suggest that this reflects the growth of magnetite from iron sulphides (Kądziałko-Hofmokl 2002), for example secondary monoclinic pyrrhotite. On the other hand, the deflection of the susceptibility curve around $450^{\circ} \mathrm{C}$ can be associated with chemical and mineralogical changes in paramagnetic minerals, leading to the formation of a new ferrimagnetic phase (Magiera, 2004).

Generally, a significant enhancement of susceptibility can be seen on cooling curves. The ratio of a magnetic susceptibility after the heating - cooling cycle $\left(\kappa_{a}\right)$ and its initial susceptibility $\left(\kappa_{i}\right)$ is 43 for the sample collected in the area of the anomaly (Fig. 4A) and 44 for the sample outside the anomaly (Fig. 4B).
A

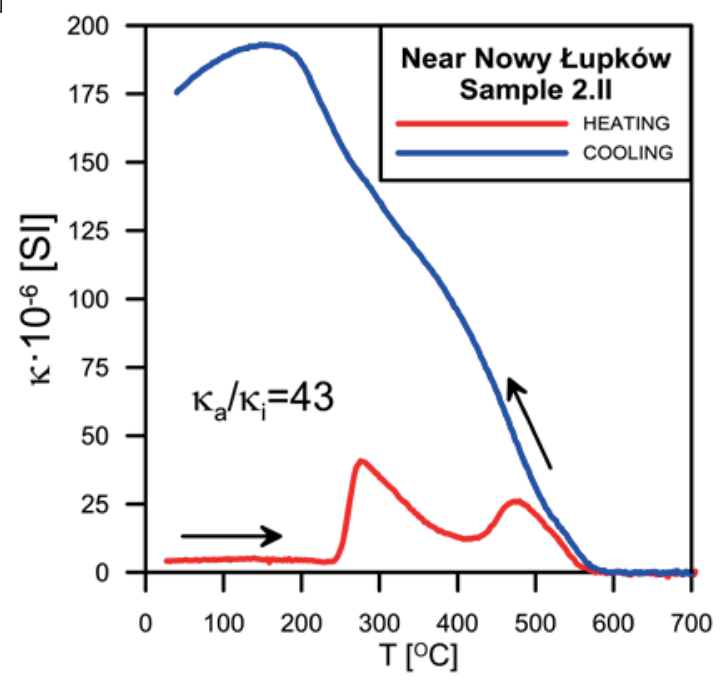

B

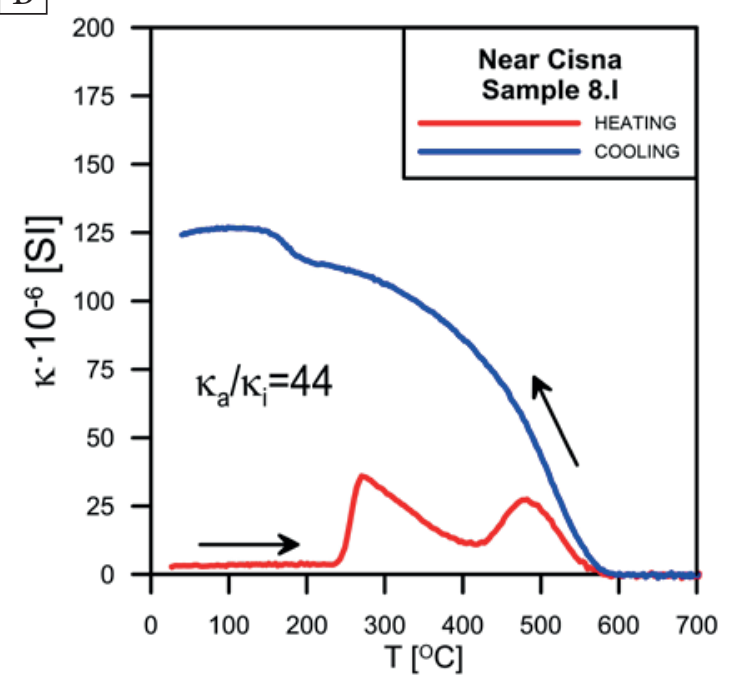

Fig. 4. Susceptibility changes during continuous heating for sample: A) 2.II from the anomaly area (near Nowy Łupków); B) 8.I from the outside of the anomaly (near Cisna); $\kappa_{i}$ is an initial susceptibility, $\kappa_{a}$ is a susceptibility after the heating-cooling cycle 
Contrary to $\kappa(T)$, magnetite is not observed on the curves of continuous thermal demagnetization of saturation isothermal remanence (Fig. 5). For the sample from the anomaly area, a rapid drop on the curve of SIRM decay before $300^{\circ} \mathrm{C}$ (Fig. 5A) can be seen. It can be explained by the presence of sulphides like pyrrhotite, with unblocking temperature $T_{u b} \approx 325^{\circ} \mathrm{C}$ (Dekkers 1989, Jeleńska et al. 2010). An inflexion point near $300^{\circ} \mathrm{C}$ indicates the transformation of metastable maghemite into hematite (Lowrie 2007). The unblocking temperature of $675^{\circ} \mathrm{C}$ is characteristic for hematite or sometimes maghemite, which is non-stoichiometric (Kądziałko-Hofmokl 2002). The behaviour of the curve for sample 8.I (from the outside the anomaly) is slightly different (Fig. 5B). The inflexion point near $300^{\circ} \mathrm{C}$ is almost unnoticeable. The unblocking temperature is also about $670^{\circ} \mathrm{C}$, but the hematite tail is more conspicuous, pointing to a higher concentration of hematite in the sample from the outside of the anomaly area.
$\mathrm{A}$

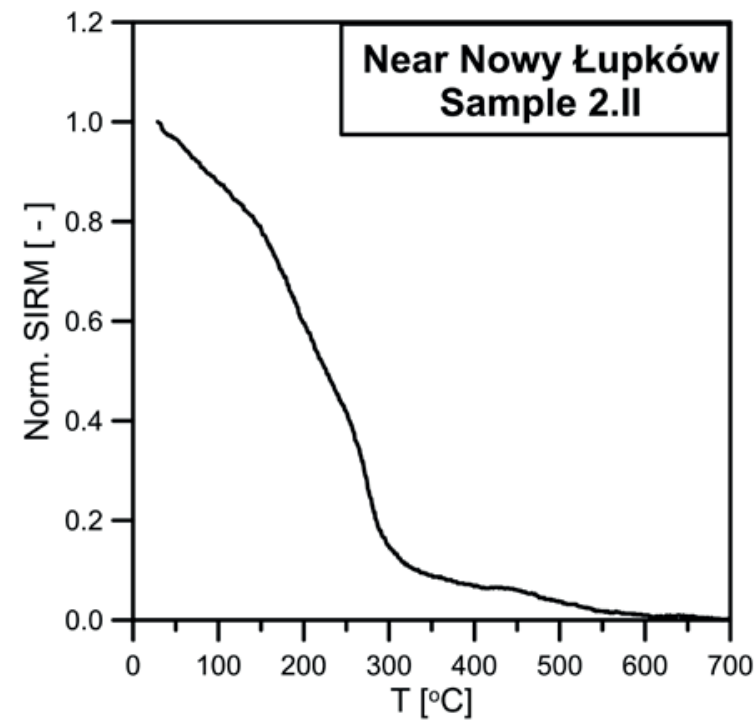

$\mathrm{B}$

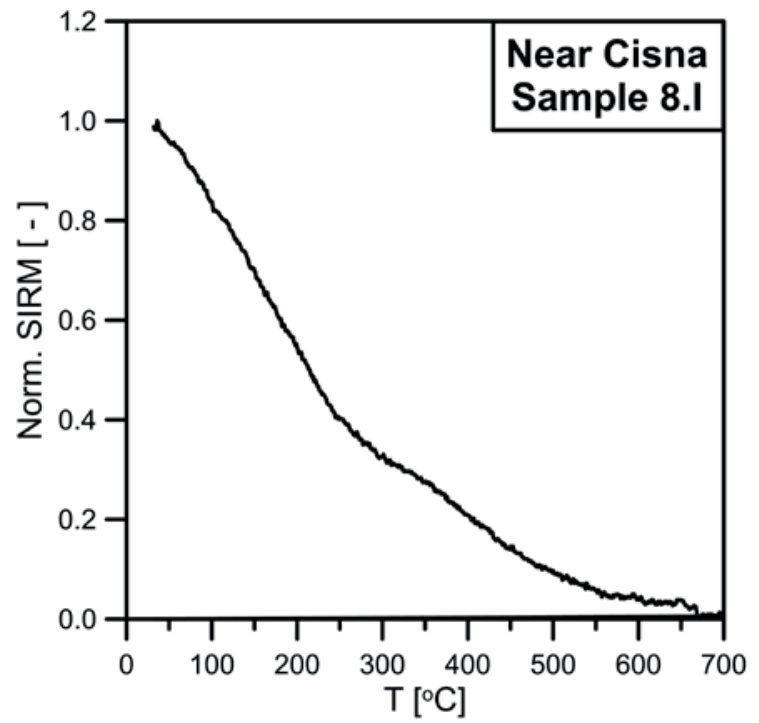

Fig. 5. SIRM demagnetization curves for sample: A) 2.II from the anomaly area (near Nowy Łupków); B) 8.I from the outside of the anomaly (near Cisna)

Figure 6 shows examples of the hysteresis loops for two samples: the first, from the anomaly area (Fig. 6A, B) and the second, from the outside the anomaly (Fig. 6C, D). Loops for both samples exhibit similar behaviour. A major paramagnetic contribution can be observed (Fig. 6A, C).

Hysteresis parameters $\left(M_{r s}, M_{s}, B_{c}\right)$ were calculated after subtracting the paramagnetic contribution. Values of $B_{c r}$ were estimated from the backfield demagnetization curves. Coercive force $\left(B_{c}\right)$ of samples ranges from $6.0 \mathrm{mT}$ to $10.5 \mathrm{mT}$, the coercivity of remanence $\left(\mathrm{B}_{\mathrm{cr}}\right)$ from $18.5 \mathrm{mT}$ to $36.5 \mathrm{mT}$, whereas saturation magnetization $\left(M_{s}\right)$ from 7.7 to $58.9 \cdot 10^{-3} \mathrm{~A} \cdot \mathrm{m}^{2} \cdot \mathrm{kg}^{-1}$ and saturation remanent isothermal magnetization $\left(M_{r s}\right)$ from 1.0 to $6.6 \cdot 10^{-3} \mathrm{~A} \cdot \mathrm{m}^{2} \cdot \mathrm{kg}^{-1}$. Consequently, $M_{r s} / M_{s}$ and $B_{c r} / B_{c}$ fall into relatively narrow ranges $0.04-0.18$ and 2.75-5.00, respectively.

In order to assess the grain size distribution, the Day plot (Day et al. 1977) modified by Dunlop (2002) was constructed for all the topsoil samples (Fig. 7). It indicates PSD grains and a mixture of $\mathrm{SD} / \mathrm{MD}$ particles with a prevalence of MD grains (Fig. 7).

The values of anhysteretic remanent susceptibility range from $28.65-86.85 \cdot 10^{-8} \mathrm{~m}^{3} \cdot \mathrm{kg}^{-1}$. Based on a $\chi_{\text {ARM }}$ and mass magnetic susceptibility compilation (King diagram), we suggest the prevalence of PSD grains (of diameter ca. $0.2-1 \mu \mathrm{m}$ ) in the studied soil samples. 


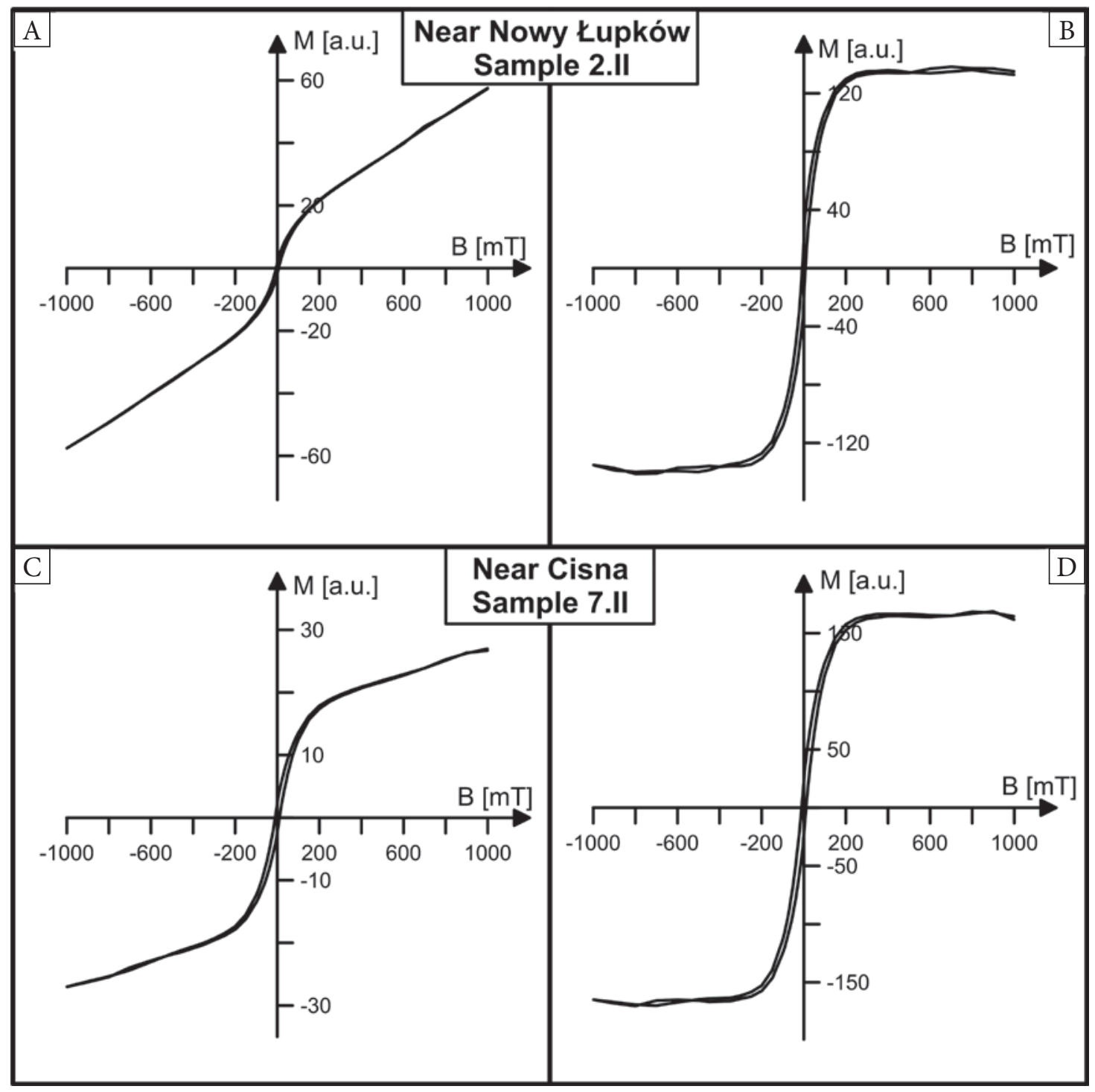

Fig. 6. Examples of the hysteresis loops for sample: 2.II from the anomaly area (near Nowy Łupków) (A, B); 7.II from the outside the anomaly (near Cisna) $(C, D)$; loops on the right $(B, D)$ were obtained after subtracting the paramagnetic contribution

\section{DISCUSSION}

In the Cisna-Wetlina Landscape Park, relatively low magnetic susceptibilities of soils were noted. The values of $\chi$ do not exceed $40 \cdot 10^{-8} \mathrm{~m}^{3} \cdot \mathrm{kg}^{-1}$ (Tab. 1) and roughly fall into the range of $\chi$ for non-polluted, Carpathian, brown and sour soils. Therefore, we state that the soils in the studied area are not polluted nowadays.

Our conclusion is reinforced by the fact, that the nearest industrial complex is located over 80 $\mathrm{km}$ from the investigated area, and there is no other potential source of pollution.
Received values of susceptibility differ clearly from the results of Magiera et al. (2002a). In that paper, on the Map of magnetic susceptibility of soils in Poland, an anomaly in the area of Cisna-Wetlina Landscape Park was noted. It is based on two values exceeding $200 \cdot 10^{-8} \mathrm{~m}^{3} \cdot \mathrm{kg}^{-1}$ (Fig. 2). The map was constructed on the basis of magnetic susceptibility of topsoil samples, measured with the use of the same instrument (MS2 Bartington apparatus with MS2B sensor). The samples were collected in 1991-1992 (Lis \& Pasieczna 1995) in $5 \times 5 \mathrm{~km}$ grid.

The susceptibility vs. depth curves exhibit similar behaviour: low values at the bottom part and 


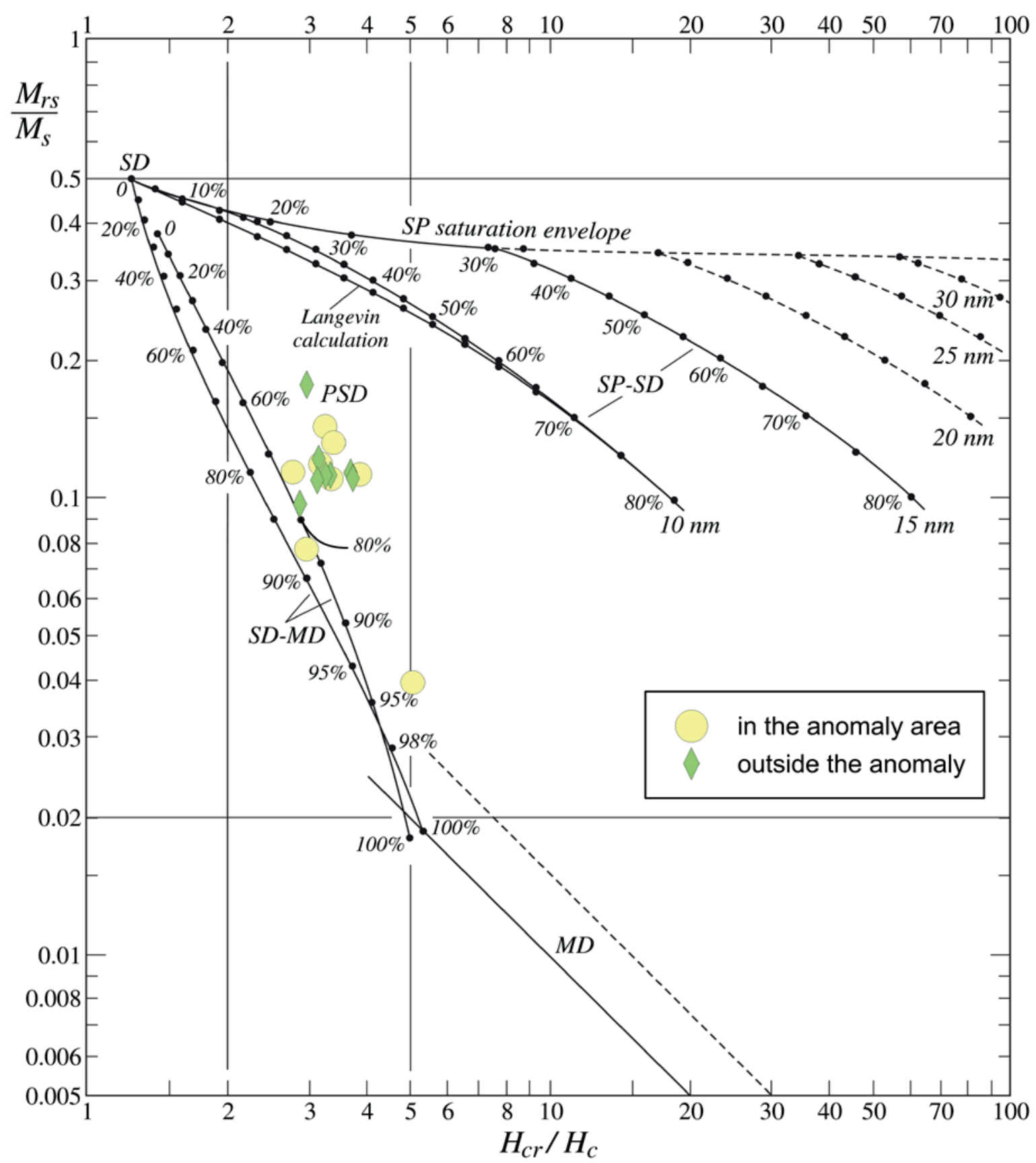

Fig. 7. The Day diagram modified by Dunlop (2002) for collected topsoil samples

increasing towards the top of the profile, reaching nearly $12 \cdot 10^{-8} \mathrm{~m}^{3} \cdot \mathrm{kg}^{-1}$ for the sample from the anomaly area and $19 \cdot 10^{-8} \mathrm{~m}^{3} \cdot \mathrm{kg}^{-1}$ for the sample from the area outside of the anomaly (Fig. 3). The enhancement of $\chi$ at the top may be due to pedogenic processes occurring in soil and climatic conditions.

The thermal treatments of the samples have revealed the presence of pyrrhotite on the SIRM(T) curves reflected by a notable decrease of magnetization before $300^{\circ} \mathrm{C}$ (Fig. 5). This result is further supported by an enhancement of susceptibility around $280^{\circ} \mathrm{C}$ on the $\kappa(T)$ curves (Fig. 4). The unblocking temperature of $670^{\circ}$ and the inflexion point near $300^{\circ} \mathrm{C}$ on the SIRM thermal decay curves (Fig. 5) point to maghemite associated with hematite. For the sample from the outside of the anomaly (8.I), the deflection on the SIRM(T) curve 
around $300^{\circ} \mathrm{C}$ is less evident, poining to the prevalence of hematite among other magnetic minerals. The presence of hematite in the topsoil indicates the maturity of the soil (Liu et al. 2005). The decrease of susceptibility in the range $280-400^{\circ} \mathrm{C}$ on the $\kappa(T)$ heating curves can also be related to the transformation of maghemite. Magnetite is observed on the $\kappa(T)$ curves (Fig. 4), although we have not found the evidence of magnetite on the SIRM decay curves (Fig. 5). Consequently, we assert, that its evidence on the $\kappa(T)$ curves is a consequence of the production of magnetite during thermal treatments. It is worth adding that our results are similar to those obtained by Jeleńska et al. (2004) for non-polluted chernozem soils.

The studies of the hysteresis loops have revealed a significant influence of the paramagnetic minerals on the magnetic properties of the collected soil samples (Fig. 6A, C). Hysteresis loops for all the specimens are relatively narrow, indicating the prevalence of soft magnetic minerals, and therefore, that the presence of high amounts of hematite is doubtful. What is more, there are no clear differences between loops obtained for the samples from the anomaly area and those from the outside the anomaly.

The investigation of hysteresis parameters has shown that the ratios $M_{r s} / M_{s}$ and $H_{c r} / H_{c}$ range in relatively narrow intervals: $0.04-0.18$ and $2.75-$ 5.00 , respectively. It points to the prevalence of PSD grains and alternatively a mixture of SD/MD particles (Fig. 7). However, studies of anhysteretic remanent susceptibility clearly indicate the presence of only PSD grains $(0.2-1 \mu \mathrm{m})$. The absence of $\mathrm{MD}$ grains in the samples shows that the soil is probably uncontaminated in the effect of industrial dust deposition. Technogenic magnetic particles (TMPs) formed during various technological processes in high temperatures usually contain MD grains (Strzyszcz et al. 1996).

\section{CONCLUSIONS}

The study has revealed that soils in the Cisna-Wetlina Landscape Park are probably notpolluted nowadays. Very low values of magnetic susceptibility have been noted. Furthermore, the lack of TMPs has been confirmed by the absence of MD grains in the investigated samples.
The results presented in this article differ significantly from those obtained by Magiera et al. (2002a) for samples collected in the studied area over twenty years ago. It can be concluded, that the anomaly of the topsoil magnetic susceptibility, which was found in the region of the Cisna-Wetlina Landscape Park, does not exist nowadays. Moreover, the same grain size distribution and magnetic minerals present in soils from the anomaly area and from the outside of the anomaly have been observed. It is difficult to give an exact explanation of the factors providing such a decrease in soil magnetic susceptibility (probably rainfall or pedogenic processes). It should be mentioned that the obtained values of magnetic susceptibility fall into the range obtained by Magiera et al. (2002a) for other Carpathian soils (with the exception of the Cisna-Wetlina Landscape Park).

Significant contribution of the paramagnetic phase in soils has been noted. Moreover, thermomagnetic investigations $(\kappa(T)$ and $\operatorname{SIRM}(T))$, hysteresis analysis and anhysteretic remanent susceptibility have revealed the presence of PSD $(0.2-1 \mu \mathrm{m})$ grains of pyrrhotite and maghemite associated with hematite. The content of hematite in the samples is evidence of the maturity of soil. The obtained results are similar with those obtained for non-polluted chernozem soils from Ukraine.

We are very grateful to the Institute of Geophysics, Polish Academy of Sciences for providing us with the access to the Paleomagnetic Laboratory and to Ph.D. Beata Górka-Kostrubiec and M.Sc. Sylwia Dytlow for helping with the measurements. Thanks are also due to Reviewers, whose remarks have made the paper much better.

\section{REFERENCES}

Boer C.B. de \& Dekkers M.J., 1996. Grain-size dependence of the rock magnetic properties for natural maghemite. Geophysical Research Letters, 23, 2815-2818.

Day R., Fuller M. \& Schmidt V.A., 1977. Hysteresis properties of titanomagnetites: grain-size and compositional dependence. Physics of the Earth and Planetary Interiors, $13,260-267$.

Dekkers M.J., 1989. Magnetic properties of natural pyrrhotite. II. High- and low-temperature behaviour of $\mathrm{J}_{\mathrm{rs}}$ and TRM as function of grain size. Physics of the Earth and Planetary Interiors, 57, 266-283. 
Dunlop D.J., 2002. Theory and application of the Day plot $\left(\mathrm{M}_{\mathrm{rs}} / \mathrm{M}_{\mathrm{s}}\right.$ versus $\left.\mathrm{H}_{\mathrm{cr}} / \mathrm{H}_{\mathrm{c}}\right)$. 1. Theoretical curves and tests using titanomagnetite data. Journal of Geophysical Research, vol. 107, no. B3, 2056.

Dunlop D.J. \& Özdemir Ö., 2007. Magnetizations in Rocks and Minerals. [in:] Schubert G. \& Kono M. (eds), Treatise on Geophysics. Vol. 5, Geomagnetism, Academic Press Elsevier Science, 278-331.

Evans M.E. \& Heller F., 2003. Environmental Magnetism. Principles and Applications of Enviromagnetics. Elsevier Science, USA.

Górka-Kostrubiec B., Jeleńska M. \& Król E., 2014. Magnetic Signature if Indoor Air Pollution: Household Dust Study. Acta Geophysica, 62, 6, 1478-1503.

Grabowska T., 2013. Magnetometria stosowana w badaniach środowiska. Tom 2: Środowiskowe parametry magnetyczne, magnetometria $w$ archeologii, magnetoklimatologia, Wydawnictwa AGH, Kraków.

Gucik S., Ślączka A. \& Żytko K. (red.), 1973. Przewodnik geologiczny po wschodnich Karpatach fliszowych. Wydawnictwa Geologiczne, Warszawa.

Heller F. \& Evans M.E., 1995. Loess magnetism. Reviews of Geophysics, 33, 2, 211-240.

Jeleńska M., Hasso-Agopsowicz A., Kopcewicz B., Sukhorada A., Tyamina K., Kądziałko-Hofmokl M. \& Matviishina Zh., 2004. Magnetic properties of the profiles of polluted and non-polluted soils. A case study from Ukraine. Geophysical Journal International, 159, 1, 104-116.

Jeleńska M., Hasso-Agopsowicz A., Kądziałko-Hofmokl M., Sukhorada A., Bondar K. \& Matviishina Zh., 2008. Magnetic iron oxides occurring in chernozem soil from Ukraine and Poland as indicators of pedogenic processes. Studia Geophysica et Geodaetica, 52, 2, 255-270.

Jeleńska M., Hasso-Agopsowicz A. \& Kopcewicz B., 2010. Thermally induced transformation of magnetic minerals in soil based on rock magnetic study and Mössbauer analysis. Physics and the Earth and Planetary Interiors, $179,3-4,164-177$.

Jordanova D., Jordanova N., Lanos P., Petrov P. \& Tsacheva T., 2012. Magnetism of outdoor and indoor settled dust and its utilization as tool for revealing the effect of elevated particulate air pollution on cardiovascular mortality. Geochemistry, Geophysics, Geosystems $G^{3}, 13,8$, Q08Z49.

Rozporzadzenie Ministra Środowiska $z$ dnia 9 września $2002 r$. $w$ sprawie standardów jakości gleby oraz standardów jakości ziemi. Dz.U. 2002, nr 165, poz. 1359 [Journal of Laws 2002 No 165, item 1359].

Kądziałko-Hofmokl M., 2002. Paleomagnetyzm: badania pola magnetycznego Ziemi w jej przeszłości geologicznej. Publications of the Institute of Geophysics Polish Academy of Sciences, M-25 (347), 89-112.

Królikowski L., Kowaliński S. \& Trzciński W. (red.), 1986. Album gleb Polski. Państwowe Wydawnictwo Naukowe, Warszawa.

Kusza G., 2013. Selected magnetic properties of bottom sediments from the Turawa Lake. Proceeding of ECOpole, 7 , 1, 371-376.

Lis J. \& Pasieczna A., 1995. Atlas geochemiczny Polski. Państwowy Instytut Geologiczny, Warszawa.

Liu Q., Deng C., Yu Y., Torrent J., Jackson M.J., Banerjee S.K. \& Zhu R., 2005. Temperature dependence of magnetic susceptibility in an argon environment: implications for pedogenesis of Chinese less/palaeosols. Geophysical Journal International, 161, 1, 102-112.

Lowrie W., 2007. Fundamentals of Geophysics. University Press, Cambridge.

Magiera T., Lis J., Nawrocki J. \& Strzyszcz Z., 2002a. Podatność magnetyczna gleb Polski. Instytut Podstaw Inżynierii Środowiska PAN, Zabrze.

Magiera T., Strzyszcz Z. \& Kostecki M., 2002b. Seasonal changes of magnetic susceptibility in sediments from Lake Żywiec (South Poland). Water, Air and Soil Pollution, 141, 1-4, 55-57.

Magiera T. \& Strzyszcz Z., 2003. Using of Magnetic Susceptibility as an Ecological Tracer for Preventive and Sanitative Actions in Soil Protection. Mitteilungen der Deutschen Bodenkundlischen Gesellschaft, 102, 2, 781-782.

Magiera T., 2004. Wykorzystanie magnetometrii do oceny zanieczyszczenia gleb i osadów jeziornych. Prace i Studia - Polska Akademia Nauk. Instytut Podstaw Inżynierii Środowiska 59, IPIŚ PAN, Zabrze.

Magiera T., Kapička A., Petrovský E., Strzyszcz Z., Fialová H. \& Rachwał M., 2008. Magnetic anomalies of forest soils in the Upper Silesia-Northern Moravia region. Environmental Pollution, 156, 3, 618-627.

Magiera T., Jabłońska M., Strzyszcz Z. \& Rachwał M., 2011a. Morphological and mineralogical forms of technogenic magnetic particles in industrial dusts. Atmospheric Environment, 45, 25, 4281-4290.

Magiera T., Jankowski M., Światoniak M. \& Rachwał M., 2011b. Study of forest soils on an area of magnetic and geochemical anomaly in North-eastern Poland. Geoder$m a, 160,559-568$.

Oorschot I.H.M. van, 2001. Chemical distinction between lithogenic and pedogenic iron oxides in environmental magnetism. A search for the perfect solution. Geologia Ultraiectina 208, Universiteit Utrecht.

Peters C. \& Dekkers M.J., 2003. Selected room temperature magnetic parameters as a function of mineralogy, concentration and grain size. Physics and Chemistry of the Earth, 28, 659-667.

Rodríguez-Germade I., Mohamed K.J., Rey D., Rubio B. \& García Á., 2014. The influence of weather and climate on the reliability of magnetic properties of tree leaves as proxies for air pollution monitoring. Science of the Total Environment, 468-469, 892-902.

Sagnotti L., Taddeucci J., Winkler A. \& Cavallo A., 2009. Compositional, morphological, and hysteresis characterization of magnetic airborne particulate matter in Rome, Italy. Geochemistry, Geophysics, Geosystems $G^{3}, 10,8$.

Strzyszcz Z., Magiera T. \& Heller F., 1996. The influence of industrial immissions on the magnetic susceptibility of soils in upper Silesia. Studia Geophysica et Geodaetica, 40/3, 276-286.

Strzyszcz Z. \& Magiera T., 2001. Record of industrial pollution in Polish ombrotrophic peat bogs. Physics and Chemistry of the Earth, 26, 11-12, 859-866.

Strzyszcz Z. \& Rachwał M., 2010. Zastosowanie magnetometrii do monitoringu i oceny ekologicznej gleb na obszarach objętych wplywem emisji przemysłowych. Prace i Studia - Polska Akademia Nauk. Instytut Podstaw Inżynierii Środowiska 78, IPIŚ PAN, Zabrze. 
Szönyi M., Sagnotti L. \& Hirt A.M., 2007. On leaf magnetic homogeneity in particulate matter biomonitoring studies. Geophysical Research Letters, 34, L06306.

Wojas A., 2009. Badania podatności magnetycznej gleb miejskich w Krakowie. Geologia - kwartalnik Akademii Górniczo-Hutniczej im. Stanisława Staszica w Krakowie, $35,2 / 1,489-496$.
Wojas A., Rolirat A. \& Grabowska T., 2010. Reconnaissance investigations of magnetic susceptibility of subsoil formation in the selected areas in southern Poland. Geologia - kwartalnik Akademii Górniczo-Hutniczej im. Stanisława Staszica $w$ Krakowie, 36, 2, 241-262. 